\title{
An Exploratory Study on How Talent Management Affects Employee Retention and Job Satisfaction for Personnel Administration in Ain Shams University Egypt
}

\author{
Eglal Hafez ${ }^{1}$, Reem AbouelNeel ${ }^{1} \&$ Eahab Elsaid $^{2}$ \\ ${ }^{1}$ Faculty of Commerce, Ain Shams University, Cairo, Egypt \\ ${ }^{2}$ Finance Department, Odette School of Business, University of Windsor, Windsor, Canada \\ Correspondence: Eahab Elsaid, Finance Department, Odette School of Business, University of Windsor, 401 Sunset \\ Ave., Windsor, Ontario, N9B 3P4, Canada. Tel: 519-253-3000 ext. 4258.
}

Received: May 25, 2017

Accepted: June 13, 2017

Online Published: July 13, 2017

doi:10.5430/jms.v8n4p1

URL: https://doi.org/10.5430/jms.v8n4p1

\begin{abstract}
Our study examines how talent management affects both job satisfaction and employee retention at a public university in Egypt. The sample for the field study consists of a 105 administrative employees who work at Ain Shams University (a public university). The study instrument is a questionnaire that consists of four parts: talent management, job satisfaction, employee retention and the sample's demographic variables. The study uses Cronbach's Alpha, Ordinary Least Squares Regressions and the Kruskal-Wallis test. We find that the components of talent management (motivating outstanding performance, training and development, job enrichment) have a significant impact on job satisfaction and on employee retention but have no significant impact on the sample's demographic variables (gender, age, education and experience). The contribution of the study is to examine how talent management affects job satisfaction and employee retention in a higher educational institution in Egypt, an Arab, Muslim, Middle Eastern country. Talent management research in Arab/Muslim countries, such as Egypt, remains mostly unexamined. By researching new countries and regions, we can help provide further insight for organizations on how to adapt their talent management practices to fit different national and cultural contexts.
\end{abstract}

Keywords: Egypt, talent management, job satisfaction, employee retention, education

\section{Introduction}

In today's rapidly changing and constantly evolving global market, organizations have come to the conclusion that one of their greatest assets is the talent, skill and knowledge of their employees (Tucker, Kao and Verma, 2005; Lewis and Heckman, 2006; Collings and Mellahi, 2009). Managing talent has become a major challenge for organizations across the globe (Tarique and Schuler, 2010; Schuler, Jackson and Tarique, 2011; Scullion and Collings, 2011). The topic of talent management has started to garner a lot of attention from corporate leaders and academics since the late 1990s when McKinsey consultants coined the phrase "war of talent" in referring to the increasing importance the role of talented leaders and highly performing employees played in the success of their organizations globally (Boudreau and Ramstad, 2007; Scullion, Collings and Caligiuri, 2010; McDonnell, 2011). In a 2007 report, the Boston Consulting Group pointed out that talent management was one of the key challenges facing the HR profession in the near future (Boston Consulting Group, 2007).

\section{Literature Review}

\subsection{Talent Management}

There has been no consensus on how previous researchers view talent management. Some researchers view talent management from a human capital point of view (Cappelli, 2008), some view it as a mindset where talent is used to achieve organizational success (Creelman, 2004), or as an essential component for effective succession planning (Cheloha and Swain, 2005), or as a way to ensure that employees at all organizational levels are performing to the best of their capabilities (Redford, 2005). This lack of consensus and the absence of a precise definition, is seen by some researcher as contributing to our limited understanding of talent management (Collings and Scullion, 2009; 
Mellahi and Collings, 2010). On the other hand, there are some researchers who admit to not being able to define talent management (Frank and Taylor, 2004; Ashton and Morton, 2005).

There are three main streams of research when it comes to talent management. The first stream defines talent management as the functions, practices and activities that are typically performed by human resource departments, such as, recruitment, selection, training and development, and career and succession management (Hilton, 2000; Olsen, 2000; Byham, 2001; Heinen and O'Neil, 2004; Mercer, 2005). In this case, managing talent entails the Human Resource departments doing what they usually do but at a much faster pace, using the internet and outsourcing, and across the entire organization, rather than within the department.

The second stream of research on talent management addresses the issue of talent pools. In this case, talent management is viewed as a set of processes that are designed to facilitate the flow of the right employees at the right time into the appropriate jobs throughout the organization (Kesler, 2002; Pascal, 2004). The abovementioned processes can also be viewed as human capital planning or succession management (Jackson and Schuler, 1990; Rothwell, 1994) but can also entail regular human resource processes such as recruiting and selection (Lermusiaux, 2005). Central to these processes is forecasting the organizational staffing needs and managing the flow of employees through positions (Pascal, 2004).

The third stream of research on talent management focuses on talent generically without regard for specific positions. Accordingly, high performing individuals should be sought after, recruited, hired and handsomely rewarded regardless of their specific positions and in some cases, regardless of the organization's staffing needs. The studies by Michaels, Handfield-Jones and Axelrod (2001) and by Axelrod, Handfield-Jones and Michaels (2002) both advocate for rating employees based on their performance levels (top performers, competent performers and bottom performers) and stress that human resource departments should seek to terminate their bottom performers. In essence, the human resource departments would be viewed as "top grading" the organization by solely hiring top performers (Smart, 1999). Top grading can be viewed as staffing an entire firm, from the CEO position to the intern positions, with top performers. This stream of research regards generic talent as critical to an organization's success because it assists the Human Resource goal of managing employees to elevated performance (Buckingham and Vosburgh, 2001; Walker and Larocco, 2002) and because previous research on demographic trends views generic talent as extremely valuable (Romans and Lardner, 2005; Tucker, Kao and Verma, 2005).

There is a fourth emerging stream of research on talent management that focuses on the identification of key positions in organizations rather than on the recruitment of highly talented individuals (Collings and Mellahi, 2009). This stream of research is concerned with the identification of key positions which will have a tremendous impact on the organization's competitive advantage (Bourdreau and Ramstad, 2005; Hueslid, Beatty and Becker, 2005). After those positions are identified, the talent management strategy focuses on the development of talent pools that include highly performing and talented employees to fill those positions.

\subsubsection{Talent Management in a Global Context}

As the field of talent management gets more developed, it is essential that academics try to come to a consensus on how to define it and how to determine its intellectual boundaries (Collings, Scullion and Vaiman, 2011). However, it is key not to lose sight of the differences in how talent management will be defined, developed and applied in different national, cultural and ethnic contexts. As the field of talent management matures, comparative studies will become more and more essential. The reason being, that such studies will help counteract the over reliance on an Anglo-Saxon conceptualization when it comes to talent management which would not be an accurate reflection of the practice in different parts of the world (Luthans, Zhu and Avolio, 2006; Mellahi and Collings, 2010; Tymon, Strumpf and Doh, 2010; Scullion and Collings, 2011).

Talent management is likely to become a challenge for organizations all across the globe. Recent research has indicated that talent management will be more of a challenge for organizations operating in emerging markets (Yeung, Warner and Rowley, 2008; Tymon, Strumpf and Doh, 2010; Vaiman and Holden, 2011). Yet, with the exception of India and China, there is a scarcity of research on talent management in emerging markets (Teagarden, Meyer and Jones, 2008). It is important to note that managing employees takes different formats in different parts of the world as opposed to the U.S. where most of the research on the talent management theory has originated (Brewster, Mayrhofer, and Morley, 2004; Holt Larsen and Mayrhofer, 2006; Dickmann, Brewster and Sparrow, 2008). It is also important to note that results of previous studies conducted in the U.S. and other Western countries cannot be directly applied to Middle Eastern countries such as Egypt. Scholars and academics need to consider the cultural context when examining talent management, job satisfaction and employee retention. 


\subsubsection{Egyptian Socio-Cultural Context}

Our study examines how talent management affects both job satisfaction and employee retention in Egypt. To the best of our knowledge, very few studies have attempted to study the talent management practices in Middle Eastern, Arab and Muslim countries, like Egypt. Scarcity of data is usually cited as the main reason for the lack of research on talent management practices in in Middle Eastern, Arab and Muslim countries. One of the main contributions of the study is that by researching new countries and regions, we can help provide further insight for organizations on how to adapt their talent management practices to fit different national and cultural contexts.

In his research, Hofstede (1980) finds that Arab societies demonstrate strong uncertainty avoidance, moderate masculinity, high power distance and low individualism. Parnell and Hatem (1999) find the Egyptian culture to be a mix of Middle Eastern and Arab influences and suggest that Islam is a significant indicator of work-related values, attitudes and behaviors. There is a scarcity of research that examines the culture's impact on human resource management practices and work-related values in Middle Eastern and Arab countries (Parnell and Hatem, 1999; Yousef, 2001).

The Middle Eastern/Arabic culture affects both the human resource management practices and the organizational form. HRM practices will be focused on relationships and teams (Leat and El-Kot, 2007). Compensation and promotion are usually based on seniority and employment is viewed as long term. The organizational form, that is considered appropriate, will be hierarchical in nature, tasks will be very clearly defined and reporting relationships will be clear and based on seniority (Leat and El-Kot, 2007).

There has been significant support for Hofstede's (1980) findings. For example, Nydell (1996) reports that employees in Arab countries, including Egypt, prefer to work in one organization doing the same jobs for long periods of time, thus avoiding and reducing uncertainty. Parnell and Hatem (1999) indicate that employees in Egypt tend to always agree with their superiors and that seeking out participation from subordinates is often regarded as weak management. In the same vein, Nydell (1996) report the importance of respecting seniority in Arab countries and in Egypt.

\subsection{Hypotheses}

According to Smith, Kendall and Hulin (1969), job dissatisfaction can be defined as "the degree to which individuals feel negatively about their jobs. It is an emotional response to the tasks, as well as to the physical and social conditions associated with the workplace." However, understanding job dissatisfaction is no easy task. Personal biases and individual perspectives make it extremely difficult to specifically identify what job dissatisfaction means (Burmeister, 2004). On the other hand, Locke (1976) has defined job satisfaction as "a positive relationship characterized by pleasurable or positive state of mind resulting from the job experience." Spector (1997) explains job satisfaction as the positive emotional state that workers derive from their jobs. In Spector's (1997) view the job satisfaction is derived from certain facets or components of the job rather than the job as a whole.

It is important to note that Hulin (1991) argues that job characteristics that are found to lead to job satisfaction in one culture might not lead to job satisfaction in a different culture. For example, Rawashdeh, Al-Saraireh and Obeidat (2015) found a positive relationship between organizational culture and job satisfaction in Jordanian private aviation companies. Crossman and Abou-Zaki (2003), in their study of job satisfaction of Lebanese banking staff, found that job satisfaction is not independent in all facets and that satisfaction with one specific job facet could lead to satisfaction in another facet. In general, there have been numerous studies that have examined the antecedents and consequences of job satisfaction across different cultures (Kirkman and Shapiro, 2001; Vecernik, 2003; Huang and Van de Vliert, 2004; Spector, 2008).

Talent management strategies have to cater to what makes employees feel satisfied with their jobs. For example, professional training and development, work assignments that demand use of the employees' skills and fuel their passion and feeling connected to a large group of fellow employees. These are things that employees need in order to feel motivated and committed to their organizations.

H1. There is a correlation between the components of talent management (motivating outstanding performance, training and development, job enrichment) and job satisfaction.

As a general rule of thumb, the loss of talented employees is detrimental to any organization's performance and future success. Talented employees leave an organization for a myriad of reasons but mainly due to being unmotivated and dissatisfied with their jobs (Coff, 1997). The importance of employee retention can be examined through the Resource Based Theory of Competitive Advantage (Barney, 1986, 1991, 1997). The Resource Based Theory proposes that firms have "bundles" of resources that lead to competitive advantages. The more unique and 
difficult to replicate these bundles of resources the stronger the firm's competitive advantage (Shrader, Blackburn and Iles, 1997). Human capital resources, such as talented employees, are among the most difficult to imitate and are key to competitive advantage (Singh, Terjesen and Vinnicombe, 2008).

Training is seen as an investment into the employee development. It is one way for firms and organizations to emphasize to their employees that they are valued and respected and in turn get rewarded with employee retention and loyalty. Previous research has shown that successful organizations have a philosophy of investing in their employees (Maguire, 1995). Employees tend to remain loyal and stay at organizations that provide them with a sense of pride and value. Some of the factors that play a pivotal role in employee retention are career opportunities, organizational justice, work-life balance, potential for growth and development, organization's image and work environment (Cappelli, 2000).

H2. There is a correlation between the components of talent management (motivating outstanding performance, training and development, job enrichment) and employee retention.

Previous research has examined the effect of organizational demographic characteristics, such as, gender, age, education and tenure on job satisfaction (Clark, 1993; Clark, Oswald and Warr, 1996; Hickson and Oshagbemi, 1999; Oshagbemi, 1998, 2000a, 2000b; Kavanaugh, Duffy and Lilly, 2006). The results have been mixed between positive and negative effects and could be attributed to the interactions between the individual demographic variables.

Previous research has determined that demographic factors, such as, gender, age, education and tenure with the organization are predictors of employee turnover (Blankertz and Robinson, 1997; Jinnett and Alexander, 1999). The younger, more highly educated and less trained employees are more likely to leave than their counterparts (Manlove and Guzell, 1997). Employees who are different than their colleagues in their respective departments, when it comes to age, gender and/or ethnicity, are more likely to leave than their counterparts (Milliken and Martins, 1996). The longer the employee tenure with the organization the less likelihood of employee turnover (Gary and Phillips, 1994; Somers, 1996). Employees with advanced degrees and employees with a low-level of education are less likely to leave the firm when compared to their counterparts with moderate levels of educations (Todd and Deery-Schmitt, 1996). Vicker, 2003 used exit interviews to examine the effect of organizational demographic characteristics on voluntary employee turnover. The inclusion of demographic variables in exit interviews should help organizations identify the managerial issues impacting each demographic group and as a result do a better job in employee retention (Vicker, 2003).

To the best of our knowledge, there is no previous research that examines the relationship between talent management and the organizational demographic information, such as, gender, age, education level and years with the firm.

H3. There is a correlation between the talent management process and the sample's demographic variables (gender, age, education and experience).

\section{Method}

\subsection{Questionnaire}

The study instrument is a questionnaire that consists of four parts. The first part contains questions regarding talent management (the independent variable). The second and third part contain questions regarding job satisfaction and employee retention (the dependent variables). The fourth part contains questions about the sample's demographic variables. The authors use a Likert scale that has five points ranging from 1 for "strongly disagree" to 5 for "strongly agree." Table 1 shows the reliability coefficients that were calculated using Cronbach's Alpha. The Cronbach's Alpha values for talent management, job satisfaction and employee retention all exceed 0.7, which is an acceptable level for the reliability of the variables.

Table 1. The effect of talent management on job satisfaction and employee retention

\begin{tabular}{cc}
\hline Study Variables & Cronbach's Alpha \\
\hline Talent Management & 0.822 \\
Job Satisfaction & 0.735 \\
Employee Retention & 0.802 \\
\hline
\end{tabular}

3.2 Sample Selection 
The sample for the field study was randomly chosen from the 300 administrative employees who work at Ain Shams University. The final sample consisted of 105 employees. Of those 105 employees 45 are males and 60 are females. Nineteen are under 30 years old, 45 are between 31 to 40 years old, 24 are between 41 to 50 years old and 17 are over 50 years old. Fourteen have no undergraduate degree, 79 have an undergraduate degree and 12 have a graduate degree (master's/doctorate). Eighteen have under 5 years of experience, 20 have between 5 and 10 years of experience, 31 have between 11 and 15 years of experience and 36 have more than 15 years of experience.

Table 2. Descriptive statics for the sample's demographic variables

Panel A: Gender

\begin{tabular}{ccc}
\hline Gender & $\mathrm{N}$ & $\%$ \\
\hline Male & 45 & 42.9 \\
Female & 60 & 57.1 \\
\hline Total & 105 & 100 \\
\hline
\end{tabular}

Panel B: Age

\begin{tabular}{ccc}
\hline Age (years) & N & $\%$ \\
\hline Under 30 & 19 & 18.1 \\
From 31-40 & 45 & 42.9 \\
From 41-50 & 24 & 22.9 \\
Over 51 & 17 & 16.2 \\
\hline Total & 105 & 100 \\
\hline
\end{tabular}

Panel C: Education

\begin{tabular}{ccc}
\hline Education & $\mathrm{N}$ & $\%$ \\
\hline No undergraduate degree & 14 & 13.3 \\
Undergraduate degree & 79 & 75.2 \\
Graduate degree & 12 & 11.4 \\
\hline Total & 105 & 100 \\
\hline
\end{tabular}

Panel D: Experience

\begin{tabular}{ccc}
\hline Experience (years) & $\mathrm{N}$ & $\%$ \\
\hline Under 5 & 18 & 17.1 \\
From 5-10 & 20 & 19 \\
From 11-15 & 31 & 29.5 \\
Over 16 & 36 & 34.3 \\
\hline Total & 105 & 100 \\
\hline
\end{tabular}

Table 3 reports the descriptive statistics of the questionnaire responses for three dimensions of talent management. Panel A shows that employees accept the concept of talent management but the majority do not think that the organization is doing enough to motivate outstanding performance and talent. Panel B shows the employees feel that there are not enough training courses and development opportunities in the organization. Panel $\mathrm{C}$ shows the employees feel that the organization does not have a clear definition for talent management.

Table 3. Descriptive statistics for talent management components 
Panel A: Motivating outstanding performance

\begin{tabular}{lccccccccccccc}
\hline \multirow{2}{*}{$\begin{array}{l}\text { Question } \\
\end{array}$} & \multicolumn{2}{c}{$\begin{array}{c}\text { Strongly } \\
\text { agree }\end{array}$} & \multicolumn{2}{c}{ Agree } & \multicolumn{2}{c}{ Neutral } & \multicolumn{2}{c}{ Disagree } & \multicolumn{2}{c}{$\begin{array}{c}\text { Strongly } \\
\text { disagree }\end{array}$} & Mean & S.D. & C.V. \\
& $\mathrm{N}$ & $\%$ & $\mathrm{~N}$ & $\%$ & $\mathrm{~N}$ & $\%$ & $\mathrm{~N}$ & $\%$ & $\mathrm{~N}$ & $\%$ & & \\
\hline Question 1 & 7 & 6.7 & 16 & 15.2 & 14 & 13.3 & 42 & 40 & 26 & 24.8 & 2.39 & 1.2 & 41.84 \\
Question 2 & 7 & 6.7 & 10 & 9.5 & 21 & 20 & 38 & 36.2 & 29 & 27.6 & 2.31 & 1.17 & 42.86 \\
Question 3 & 7 & 6.7 & 11 & 10.5 & 15 & 14.3 & 38 & 36.2 & 34 & 32.4 & 2.23 & 1.2 & 43.95 \\
\hline Mean Avg. & & & & & & & & & & & 2.31 & 1.05 & 36.35 \\
\hline
\end{tabular}

C.V. is the Coefficient Variation $=($ Standard Deviation/Mean $) \times 100$

Question 1: Does the organization motivate outstanding performance?

Question 2: Does the organization compensate talented employees?

Question 3: Does the organization motivate talented employees?

Panel B: Training and development

\begin{tabular}{|c|c|c|c|c|c|c|c|c|c|c|c|c|c|}
\hline \multirow[b]{2}{*}{ Degree } & \multicolumn{2}{|c|}{$\begin{array}{c}\text { Strongly } \\
\text { agree }\end{array}$} & \multicolumn{2}{|c|}{ Agree } & \multicolumn{2}{|c|}{ Neutral } & \multicolumn{2}{|c|}{ Disagree } & \multicolumn{2}{|c|}{$\begin{array}{l}\text { Strongly } \\
\text { disagree }\end{array}$} & \multirow[t]{2}{*}{ Mean } & \multirow[t]{2}{*}{ S.D. } & \multirow[t]{2}{*}{ C.V. } \\
\hline & $\mathrm{N}$ & $\%$ & $\mathrm{~N}$ & $\%$ & $\mathrm{~N}$ & $\%$ & $\mathrm{~N}$ & $\%$ & $\mathrm{~N}$ & $\%$ & & & \\
\hline Question 1 & 69 & 65.7 & 19 & 18.1 & 6 & 5.7 & 8 & 7.6 & 3 & 2.9 & 4.36 & 1.07 & 24.66 \\
\hline Question 2 & 63 & 60 & 25 & 23.8 & 7 & 6.7 & 4 & 3.8 & 6 & 5.7 & 4.29 & 1.12 & 26.2 \\
\hline Question 3 & 3 & 2.9 & 2 & 1.9 & 11 & 10.5 & 60 & 57.1 & 29 & 27.6 & 1.95 & 0.85 & 43.49 \\
\hline Question 4 & 38 & 36.2 & 29 & 27.6 & 14 & 13.3 & 17 & 16.2 & 7 & 6.7 & 3.7 & 1.29 & 34.95 \\
\hline Mean Avg. & & & & & & & & & & & 2.86 & 0.51 & 18.14 \\
\hline
\end{tabular}

C.V. is the Coefficient Variation $=($ Standard Deviation/Mean $) \times 100$

Question 1: Does talent management play an important role in employee retention?

Question 2: Does talent management play an important role in job satisfaction?

Question 3: Does the organization have a clear definition for talent management?

Question 4: Does the organization not have enough training and development opportunities?

Panel C: Job enrichment

\begin{tabular}{|c|c|c|c|c|c|c|c|c|c|c|c|c|c|}
\hline \multirow[b]{2}{*}{ Degree } & \multicolumn{2}{|c|}{$\begin{array}{c}\text { Strongly } \\
\text { agree }\end{array}$} & \multicolumn{2}{|c|}{ Agree } & \multicolumn{2}{|c|}{ Neutral } & \multicolumn{2}{|c|}{ Disagree } & \multicolumn{2}{|c|}{$\begin{array}{l}\text { Strongly } \\
\text { disagree }\end{array}$} & \multirow[t]{2}{*}{ Mean } & \multirow[t]{2}{*}{ S.D. } & \multirow[t]{2}{*}{ C.V. } \\
\hline & $\mathrm{N}$ & $\%$ & $\mathrm{~N}$ & $\%$ & $\mathrm{~N}$ & $\%$ & $\mathrm{~N}$ & $\%$ & $\mathrm{~N}$ & $\%$ & & & \\
\hline Question 1 & 3 & 2.9 & 9 & 8.6 & 17 & 16.2 & 48 & 45.7 & 28 & 26.7 & 2.15 & 1.00 & 44.65 \\
\hline Question 2 & 7 & 6.7 & 9 & 8.6 & 26 & 24.8 & 51 & 48.6 & 12 & 11.4 & 2.01 & 0.93 & 42.79 \\
\hline Question 3 & 8 & 7.6 & 17 & 16.2 & 17 & 16.2 & 43 & 41.2 & 20 & 19 & 2.08 & 0.98 & 42.31 \\
\hline Mean Avg. & & & & & & & & & & & 2.07 & 0.83 & 39.98 \\
\hline
\end{tabular}

C.V. is the Coefficient Variation $=($ Standard Deviation/Mean $) \times 100$

Question 1: Does the organization have a clear definition for who are the talented employees?

Question 2: Does the organization provide meaningful job enrichment for the talented employees?

Question 3: Can the organization identify talented employees? 
Table 4 reports the descriptive statistics of the questionnaire responses for three dimensions of job satisfaction. Panel A shows that employees feel that the organization does not treat all its employees equally. They also feel that the organization does not value the job satisfaction of its employees. Panel B shows that employees feel that job satisfaction plays an important role when it comes to employee retentions. Panel C shows that employees feel that the organization does not have succession plans in place and does not monitor how satisfied talented employees are with their compensation and work conditions.

Table 4. Descriptive statistics for dimensions of job satisfaction

Panel A: Equality

\begin{tabular}{lccccccccccccc}
\hline & \multicolumn{2}{c}{$\begin{array}{c}\text { Strongly } \\
\text { agree }\end{array}$} & \multicolumn{2}{c}{ Agree } & \multicolumn{2}{c}{ Neutral } & \multicolumn{2}{c}{ Disagree } & \multicolumn{2}{c}{$\begin{array}{c}\text { Strongly } \\
\text { disagree }\end{array}$} & Mean & S.D. & C.V. \\
\hline Degree & $\mathrm{N}$ & $\%$ & $\mathrm{~N}$ & $\%$ & $\mathrm{~N}$ & $\%$ & $\mathrm{~N}$ & $\%$ & $\mathrm{~N}$ & $\%$ & & \\
\hline Question 1 & 8 & 7.6 & 16 & 15.2 & 19 & 18.1 & 44 & 41.9 & 18 & 17.1 & 2.54 & 1.01 & 39.76 \\
Question 2 & 10 & 9.5 & 10 & 9.5 & 16 & 15.2 & 42 & 40 & 27 & 25.7 & 2.37 & 1.00 & 42.19 \\
Question 3 & 8 & 7.6 & 17 & 16.2 & 17 & 16.2 & 43 & 41 & 20 & 19 & 2.52 & 0.98 & 38.88 \\
\hline Mean Avg. & & & & & & & & & & & & &
\end{tabular}

C.V. is the Coefficient Variation $=($ Standard Deviation/Mean $) \times 100$

Question 1: Does the organization value the concept of job satisfaction?

Question 2: Does the organization treat its employees fairly and equally?

Question 3: Do the employees feel satisfied with their jobs and work responsibilities?

Panel B: Equal opportunities

\begin{tabular}{|c|c|c|c|c|c|c|c|c|c|c|c|c|c|}
\hline \multirow[b]{2}{*}{ Degree } & \multicolumn{2}{|c|}{$\begin{array}{c}\text { Strongly } \\
\text { agree }\end{array}$} & \multicolumn{2}{|c|}{ Agree } & \multicolumn{2}{|c|}{ Neutral } & \multicolumn{2}{|c|}{ Disagree } & \multicolumn{2}{|c|}{$\begin{array}{l}\text { Strongly } \\
\text { disagree }\end{array}$} & \multirow[t]{2}{*}{ Mean } & \multirow[t]{2}{*}{ S.D. } & \multirow[t]{2}{*}{ C.V. } \\
\hline & $\mathrm{N}$ & $\%$ & $\mathrm{~N}$ & $\%$ & $\mathrm{~N}$ & $\%$ & $\mathrm{~N}$ & $\%$ & $\mathrm{~N}$ & $\%$ & & & \\
\hline Question 1 & 70 & 66.7 & 19 & 18.1 & 7 & 6.7 & 6 & 5.7 & 3 & 2.9 & 4.40 & 1.03 & 23.50 \\
\hline Question 2 & 49 & 46.7 & 28 & 26.7 & 13 & 12.4 & 9 & 8.6 & 6 & 5.7 & 4.00 & 1.21 & 30.23 \\
\hline Question 3 & 6 & 5.7 & 5 & 4.8 & 12 & 11.4 & 65 & 61.9 & 17 & 16.2 & 2.22 & 0.97 & 43.74 \\
\hline Mean Avg. & & & & & & & & & & & 3.54 & 0.80 & 22.56 \\
\hline
\end{tabular}

C.V. is the Coefficient Variation $=($ Standard Deviation/Mean $) \times 100$

Question 1: Does job satisfaction play an important role in employee retention?

Question 2: Does talent management affect job satisfaction?

Question 3: Does the organization provide equal opportunities for all its employees?

Panel C: Style of leadership

\begin{tabular}{|c|c|c|c|c|c|c|c|c|c|c|c|c|c|}
\hline \multirow[b]{2}{*}{ Degree } & \multicolumn{2}{|c|}{$\begin{array}{c}\text { Strongly } \\
\text { agree }\end{array}$} & \multicolumn{2}{|c|}{ Agree } & \multicolumn{2}{|c|}{ Neutral } & \multicolumn{2}{|c|}{ Disagree } & \multicolumn{2}{|c|}{$\begin{array}{l}\text { Strongly } \\
\text { disagree }\end{array}$} & \multirow[t]{2}{*}{ Mean } & \multirow[t]{2}{*}{ S.D. } & \multirow[t]{2}{*}{ C.V. } \\
\hline & $\mathrm{N}$ & $\%$ & $\mathrm{~N}$ & $\%$ & $\mathrm{~N}$ & $\%$ & $\mathrm{~N}$ & $\%$ & $\mathrm{~N}$ & $\%$ & & & \\
\hline Question 1 & 39 & 37.1 & 29 & 27.6 & 12 & 11.4 & 19 & 18.1 & 6 & 5.7 & 3.72 & 1.29 & 34.68 \\
\hline Question 2 & 7 & 6.7 & 9 & 8.6 & 26 & 24.8 & 51 & 48.6 & 12 & 11.4 & 2.50 & 1.03 & 41.20 \\
\hline Question 3 & 4 & 3.8 & 3 & 2.9 & 14 & 13.3 & 53 & 50.5 & 31 & 29.5 & 2.01 & 0.88 & 43.78 \\
\hline Question 4 & 9 & 8.6 & 10 & 9.5 & 15 & 14.3 & 34 & 32.4 & 37 & 35.2 & 2.24 & 0.98 & 43.75 \\
\hline Mean Avg. & & & & & & & & & & & 2.62 & 0.68 & 25.84 \\
\hline
\end{tabular}

C.V. is the Coefficient Variation $=($ Standard Deviation/Mean $) \times 100$

Question 1: Are there conflicts between talented employees and the organizational bureaucratic leadership?

Question 2: Does the organization have a democratic leadership?

Question 3: Does the organization monitor job satisfaction of talented employees concerning their compensation and working conditions?

Question 4: Does the organization have a succession plan to replace employees who retire and/or resign? 
Table 5 reports the descriptive statistics of the questionnaire responses for three dimensions of employee retention. Panel A shows that the employees feel that talent management and job satisfaction play an important role in employee retention. They also feel that the organization does not provide growth opportunities for talented employees and does not encourage employees to achieve a work-life balance. Panel B shows that the employees feel that the organization does not provide feedback and mentoring for talented employees and does not have a strategy for employee retention. Panel $\mathrm{C}$ shows that the employees feel the organization does not have meaningful communication with its employees and it does not have a clear definition for employee retention.

Table 5. Descriptive statistics for dimensions of employee retention

Panel A: Incentives

\begin{tabular}{lccccccccccccc}
\hline & \multicolumn{2}{c}{$\begin{array}{c}\text { Strongly } \\
\text { agree }\end{array}$} & \multicolumn{2}{c}{ Agree } & \multicolumn{2}{c}{ Neutral } & \multicolumn{2}{c}{ Disagree } & \multicolumn{2}{c}{$\begin{array}{c}\text { Strongly } \\
\text { disagree }\end{array}$} & Mean & S.D. & C.V. \\
\hline Degree & $\mathrm{N}$ & $\%$ & $\mathrm{~N}$ & $\%$ & $\mathrm{~N}$ & $\%$ & $\mathrm{~N}$ & $\%$ & $\mathrm{~N}$ & $\%$ & & & \\
\hline Question 1 & 56 & 53.3 & 19 & 18.1 & 12 & 11.4 & 10 & 9.5 & 8 & 7.6 & 4.00 & 1.32 & 33.00 \\
Question 2 & 59 & 56.2 & 24 & 22.9 & 8 & 7.6 & 7 & 6.7 & 7 & 6.7 & 4.15 & 1.22 & 29.40 \\
Question 3 & 8 & 7.6 & 8 & 7.6 & 24 & 22.9 & 46 & 43.8 & 19 & 18.1 & 2.43 & 0.99 & 40.74 \\
Question 4 & 32 & 30.5 & 8 & 7.6 & 29 & 27.6 & 22 & 21 & 14 & 13.3 & 3.21 & 1.42 & 44.24 \\
\hline Mean Avg. & & & & & & & & & & & & & \\
\hline
\end{tabular}

C.V. is the Coefficient Variation $=($ Standard Deviation/Mean $) \times 100$

Question 1: Does talent management play an important role in employee retention?

Question 2: Does job satisfaction lead to employee retention?

Question 3: Does the organization provide growth opportunities for its talented employees?

Question 4: Does the organization encourage employees to achieve a work-life balance?

Panel B: Feedback

\begin{tabular}{lccccccccccccc}
\hline & \multicolumn{2}{c}{$\begin{array}{c}\text { Strongly } \\
\text { agree }\end{array}$} & \multicolumn{2}{c}{ Agree } & \multicolumn{2}{c}{ Neutral } & \multicolumn{2}{c}{ Disagree } & \multicolumn{2}{c}{$\begin{array}{c}\text { Strongly } \\
\text { disagree }\end{array}$} & Mean & S.D. & C.V. \\
\hline Degree & $\mathrm{N}$ & $\%$ & $\mathrm{~N}$ & $\%$ & $\mathrm{~N}$ & $\%$ & $\mathrm{~N}$ & $\%$ & $\mathrm{~N}$ & $\%$ & & & \\
\hline Question 1 & 5 & 4.8 & 8 & 7.6 & 23 & 21.9 & 50 & 47.6 & 19 & 18.1 & 2.33 & 1.02 & 43.78 \\
Question 2 & 16 & 15.2 & 21 & 20 & 16 & 15.2 & 36 & 34.3 & 16 & 15.2 & 2.86 & 1.00 & 34.97 \\
Question 3 & 2 & 1.9 & 16 & 15.2 & 24 & 22.9 & 37 & 35.2 & 26 & 24.8 & 2.34 & 1.00 & 42.74 \\
\hline Mean Avg. & & & & & & & & & & 1.88 & 0.66 & 35.11 \\
\hline
\end{tabular}

C.V. is the Coefficient Variation $=($ Standard Deviation/Mean $) \times 100$

Question 1: Does the organization provide feedback and mentoring for key employees?

Question 2: Does the organization have a strategy for employee retention?

Question 3: Does the organization implement its strategy for employee retention?

Panel C: Communication

\begin{tabular}{|c|c|c|c|c|c|c|c|c|c|c|c|c|c|}
\hline \multirow[b]{2}{*}{ Degree } & \multicolumn{2}{|c|}{$\begin{array}{c}\text { Strongly } \\
\text { agree }\end{array}$} & \multicolumn{2}{|c|}{ Agree } & \multicolumn{2}{|c|}{ Neutral } & \multicolumn{2}{|c|}{ Disagree } & \multicolumn{2}{|c|}{$\begin{array}{l}\text { Strongly } \\
\text { disagree }\end{array}$} & \multirow[t]{2}{*}{ Mean } & \multirow[t]{2}{*}{ S.D. } & \multirow[t]{2}{*}{ C.V. } \\
\hline & $\mathrm{N}$ & $\%$ & $\mathrm{~N}$ & $\%$ & $\mathrm{~N}$ & $\%$ & $\mathrm{~N}$ & $\%$ & $\mathrm{~N}$ & $\%$ & & & \\
\hline Question 1 & 7 & 6.7 & 31 & 29.5 & 19 & 18.1 & 39 & 37.1 & 9 & 8.6 & 2.89 & 1.13 & 39.10 \\
\hline Question 2 & 24 & 22.9 & 18 & 17.1 & 28 & 26.7 & 26 & 24.8 & 9 & 8.6 & 3.21 & 1.28 & 39.88 \\
\hline Question 3 & 3 & 2.9 & 11 & 10.5 & 24 & 22.9 & 44 & 41.9 & 23 & 21.9 & 2.30 & 1.02 & 44.35 \\
\hline Mean Avg. & & & & & & & & & & & 2.10 & 0.57 & 27.14 \\
\hline
\end{tabular}

C.V. is the Coefficient Variation $=($ Standard Deviation/Mean $) \times 100$

Question 1: Does the organization have meaningful communication with its employees?

Question 2: Does the organization recognize when the employees' workload is too heavy?

Question 3: Does the organization have a clear definition for employee retention? 
Table 6 reports the summary descriptive statistics for the effect of talent management on job satisfaction and employee retention. Table 6 shows that the employees feel that talent management does have an impact on job satisfaction and employee retention.

Table 6. Summary descriptive statistics for the effect of talent management on job satisfaction and employee retention

\begin{tabular}{cccc}
\hline Variable & Mean & S.D. & C.V. \\
\hline Talent Management & 2.29 & 0.46 & 20.34 \\
Job Satisfaction & 2.85 & 0.64 & 22.40 \\
Employee Retentions & 2.97 & 0.73 & 24.58 \\
\hline Mean Avg. & 2.70 & 0.51 & 18.88 \\
\hline
\end{tabular}

C.V. is the Coefficient Variation $=($ Standard Deviation/Mean $) \times 100$

\subsection{Procedure}

The questionnaires were translated from English to Arabic since most of the 105 employees in our sample are not proficient in English. The Werner and Campbell (1976), decentring method which is based on the back-translation procedure that is commonly used in cross-cultural research (Zhang, 1991; Brislin, 1976) was used to translate the questionnaires from English to Arabic. The questionnaires were originally in English, and one of the authors who is a fluently bilingual native Egyptian translated the questionnaires into the Arabic language. A different author who is also fluently bilingual native Egyptian blindly translated the questionnaires back into the original language, English. The original and translated English language questionnaires were compared and examined for differences and it was determined that no differences existed between the two English language questionnaires. Thus, no adjustments were needed.

\section{Methodology and Results}

Table 7 reports the correlation between the job satisfaction and employee retention variables and the talent management variable. The correlations are positive and significant which indicates that the better the status of the talent management practices the higher the job satisfaction and the employee retention.

Table 7. Correlation between job satisfaction, employee retention and talent management

\begin{tabular}{ccc}
\cline { 2 - 2 } Job Satisfaction & Talent Management (Pearson Correlation) \\
\cline { 2 - 3 } Employee Retentions & $0.568 * * *$ \\
\hline E* Significant at $0.00, * *$ Significant at $0.01, *$ Significant at 0.05
\end{tabular}

To test Hypothesis 1 (2) the authors run an ordinary least squares regression where the dependent variable is job satisfaction (employee retention) and the independent variables are the components of talent management (motivating outstanding performance; training and development and job enrichment). The results for this regression are reported in Table 8 (9). The White-Koenker statistics given in the last line of the Tables 8 and 9 show that all of our regressions are free of heteroscedasticity (Baum et al., 2003).

Table 8 contains the OLS regression estimates for the relation between job satisfaction and talent management components (motivating outstanding performance, training and development and job enrichment). The estimated coefficients for motivating outstanding performance and training and development are significant and positive. However, we find that the job enrichment independent variable has no effect on the job satisfaction dependent variable. Therefore, the authors accept Hypothesis 1 since two of the three components of talent management were found to have a significant impact on job satisfaction. 
Table 8. OLS Estimates for Hypothesis 1: There is a significant impact between the dimensions of talent management (motivating outstanding performance, training and development, job enrichment) and job satisfaction ( $t$ statistics in brackets)

\begin{tabular}{cc}
\hline & Job \\
& Satisfaction \\
\cline { 2 - 3 } Constant & 1.399 \\
Motivating outstanding & $(5.002)^{* * *}$ \\
performance & 0.347 \\
Training and development & $(7.398)^{* * *}$ \\
& 0.228 \\
Job Enrichment & $(2.380)^{*}$ \\
& -- \\
Adjusted $\mathrm{R}^{2}$ & -- \\
(F) & $40.4 \%$ \\
$\mathrm{~N}$ & $(35.584)^{* * *}$ \\
& 105 \\
White-Koenker & 12.698 \\
\hline
\end{tabular}

*** Significant at $0.001, * *$ Significant at $0.01, *$ Significant at 0.05

Table 9 contains the OLS regression estimates for the relation between employee retention and talent management components (motivating outstanding performance, training and development and job enrichment). The estimated coefficients for training and development and job enrichment are significant and positive. However, we find that the motivating outstanding performance independent variable has no effect on the employee retention dependent variable. Therefore, the authors accept Hypothesis 2 since two of the three components of talent management were found to have a significant impact on employee retention.

Table 9. OLS Estimates for Hypothesis 2: There is a significant impact between the dimensions of talent management (motivating outstanding performance, training and development, job enrichment) and employee retention ( $\mathrm{t}$ statistics in brackets)

\begin{tabular}{cc}
\hline & $\begin{array}{c}\text { Employee } \\
\text { Retention }\end{array}$ \\
& \\
\hline Constant & 1.356 \\
& $(3.741)^{* * *}$ \\
Motivating outstanding & -- \\
performance & -- \\
Training and development & 0.313 \\
& $(2.549)^{*}$ \\
Job Enrichment & 0.347 \\
& $(4.521)^{* * *}$ \\
Adjusted $\mathrm{R}^{2}$ & $24.2 \%$ \\
(F) & $(16.258)^{* * *}$ \\
$\mathrm{~N}$ & 105 \\
& 13.804 \\
\hline
\end{tabular}

*** Significant at $0.001, * *$ Significant at $0.01, *$ Significant at 0.05 
Table 10 reports the results of the Kruskal-Wallis test that were run to determine if there is a difference in the responses based on gender (Panel A), age (Panel B), education (Panel C) and experience (Panel D) to the positive impact of talent management on job satisfaction and employee retention. We found no significant differences between gender, age, education and experience to the positive impact of talent management on job satisfaction and employee retention. Therefore, the authors reject Hypothesis 3 that states that there is a significant difference between the talent management process and the sample's demographic variables (gender, age, education and experience).

Table 10. Kruskal-Wallis Test for Hypothesis 3: There is a significant difference between the talent management process and the sample's demographic variables (gender, age, education and experience).

Panel A: Differences between gender and the impact of talent management on job satisfaction and employee retention

\begin{tabular}{|c|c|c|c|c|c|}
\hline & Gender & $\mathrm{N}$ & Mean & Chi-square & $\mathrm{P}$-value \\
\hline \multirow[t]{2}{*}{ Talent Management } & Male & 45 & 52.6 & 0.117 & 0.9 \\
\hline & Female & 60 & 53.3 & & \\
\hline \multirow[t]{2}{*}{ Job Satisfaction } & Male & 45 & 51.17 & 0.537 & 0.59 \\
\hline & Female & 60 & 54.38 & & \\
\hline \multirow[t]{2}{*}{ Employee Retention } & Male & 45 & 49.13 & 1.128 & 0.25 \\
\hline & Female & 60 & 55.90 & & \\
\hline
\end{tabular}

*** Significant at $0.001, * *$ Significant at $0.01, *$ Significant at 0.05

Panel B: Differences between age and the impact of talent management on job satisfaction and employee retention

\begin{tabular}{cccccc}
\hline & Age (years) & N & Mean & Chi-square & P-value \\
\hline Talent Management & Under 30 & 19 & 42.11 & 6.657 & 0.08 \\
& From 31-40 & 45 & 49.53 & & \\
& From 41-50 & 24 & 63.27 & & \\
& Over 51 & 17 & 59.85 & & \\
\hline Job Satisfaction & Under 30 & 19 & 42.97 & 5.428 & 0.14 \\
& From 31-40 & 45 & 51.60 & & \\
& From 41-50 & 24 & 64.15 & & \\
Employee Retention & Over 51 & 17 & 52.18 & & \\
& Under 30 & 19 & 61.84 & 3.344 & 0.34 \\
& From 31-40 & 45 & 47.37 & & \\
& From 41-50 & 24 & 55.08 & & \\
& Over 51 & 17 & 55.09 & & \\
\hline
\end{tabular}

*** Significant at $0.001, * *$ Significant at $0.01, *$ Significant at 0.05 
Panel C: Differences between education and the impact of talent management on job satisfaction and employee retention

\begin{tabular}{cccccc}
\hline & Education & $\mathrm{N}$ & Mean & Chi-square & P-value \\
\hline Talent Management & No undergraduate degree & 14 & 55.82 & 0.174 & 0.91 \\
& Undergraduate degree & 79 & 52.34 & & \\
& Graduate degree & 12 & 54.08 & & \\
\hline \multirow{2}{*}{ Job Satisfaction } & No undergraduate degree & 14 & 48.50 & 0.631 & \multirow{2}{*}{0.73} \\
& Undergraduate degree & 79 & 54.34 & & \\
& Graduate degree & 12 & 49.42 & & \\
\cline { 1 - 2 } Employee Retention & No undergraduate degree & 14 & 50.46 & \multirow{2}{*}{2.094} & \multirow{2}{*}{0.35} \\
& Undergraduate degree & 79 & 55.14 & & \\
& Graduate degree & 12 & 41.88 & & \\
\hline
\end{tabular}

Panel D: Differences between experience and the impact of talent management on job satisfaction and employee retention

\begin{tabular}{cccccc}
\hline & Experience (years) & N & Mean & Chi-square & P-value \\
\hline Talent Management & Under 5 & 18 & 54.53 & 4.700 & 0.19 \\
& From 5-10 & 20 & 55.58 & & \\
& From 11-15 & 31 & 43.44 & & \\
& Over 16 & 36 & 59.04 & & \\
\hline Job Satisfaction & Under 5 & 18 & 44.25 & 3.272 & 0.35 \\
& From 5-10 & 20 & 59.75 & & \\
& From 11-15 & 31 & 49.82 & & \\
& Over 16 & 36 & 56.36 & & \\
& Under 5 & 18 & 47.03 & & 1.246 \\
Employee Retention & From 5-10 & 20 & 56.40 & & \\
& From 11-15 & 31 & 51.48 & & \\
& Over 16 & 36 & 55.40 & & \\
\end{tabular}

\section{Conclusions and Implications}

The current field study examined whether talent management has an impact on job satisfaction and employee retention at a public Egyptian university. It also examined the relationship between the sample's demographic variables (gender, age, education and experience) and talent management. Hypothesis 1 stated, "There is a significant impact between the components of talent management (motivating outstanding performance, training and development, job enrichment) and job satisfaction." The findings show that hypothesis 1 proves true since both motivating outstanding performance and training and development were found to have a significant impact on job satisfaction.

Hypothesis 2 stated, "There is a significant impact between the components of talent management (motivating outstanding performance, training and development, job enrichment) and employee retention." The findings show that hypothesis 2 proves true since both training and development and job enrichment were found to have a significant impact on employee retention.

Hypothesis 3 stated, "There is a significant difference between the talent management process and the sample's demographic variables (gender, age, education and experience)." The findings show that hypothesis 3 is rejected since there is no significant differences between gender, age, education and experience and talent management. 
The study has both theoretical and practical implications. To the best of our knowledge, no other field study in Egypt or in the Middle East has examined both job satisfaction and employee retention as a result of a talent management system or lack thereof, or the perceived importance of the former derived from the latter. As a result, our study can be considered an internal exploratory study of Human Resource paradigms with a cross-cultural lens. Our study contributes to the existing literature by focusing on the unique aspect of geographical location and the Middle Eastern/Muslim culture on general descriptions of well researched variables such as talent management, job satisfaction and employee retention. The practical implications of the study include helping Egyptian universities identify the levels of job satisfaction among their employees and determining the factors that cause their employees to leave their jobs.

\subsection{Future Research}

Researchers can extend our study to examine privately owned universities in Egypt. The study can also be extended to non-educational public sector institutions and to private sector firms in Egypt. It would be interesting to examine whether the results hold for privately owned universities, non-educational public sector institutions and private sector firms. The study can be extended to other Middle Eastern countries to examine if the results are generalizable based on geographic location and/or cultural similarity.

\subsection{Limitations}

The study's results are limited to a public Egyptian university. Another limitation of the study was the translation of the questionnaires from English to Arabic then back to English. The authors tried to overcome this limitation by using the Werner and Campbell (1976), decentring method. The authors use Egypt as an example of a Middle Eastern country. However, it should be noted that the Middle East includes countries with different cultures, such as Israel. It should also be noted that about 10\% of Egypt's population are Coptic Christians who do not necessarily share the same cultural beliefs as the country's Muslim majority (Elsaid and Elsaid, 2012).

The authors attempt to reduce the selection bias issue (Heckman, 1979) by randomly selecting 105 employees from the 300 employees working at the university. All the 105 employees in our sample completed the questionnaires during regular work hours. As a result, they could have encountered interruptions that may have affected the accuracy of their responses.

\section{References}

Ashton, C., \& Morton, L. (2005). Managing talent for competitive advantage. Strategic HR Review, 4(5), 28-31.

Axelrod, B., Handfield-Jones, H., \& Michaels, E. (2002, January). A new game plan for C players. Harvard Business Review, 80-88.

Barney, J. (1986). Organizational Culture - Can it be a Source of Sustained Competitive Advantage? Academy of Management Review, 11(3), 656-665. http://dx.doi.org/10.5465/AMR.1986.4306261

Barney, J. (1991). Firm Resources and Sustained Competitive Advantage. Journal of Management, 17(1), 99-120.

Barney, J. (1997). Gaining and Sustaining Competitive Advantage. Reading, MA: Addison Wesley.

Baum, C., Schaffer, M., \& Stillman, S. (2003). Instrumental variables and GMM: Estimation and testing. Stata Journal, 3(1), 1-31.

Blankertz, L., \& Robinson, S. (1997). Turnover intentions of community mental health workers in psychosocial rehabilitation services. Community Mental Health Journal, 33(6), 517-529.

Boston Consulting Group, (2007). The future of HR: Key challenges through 2015. Boston Consulting Group, Dousseldorf.

Bourdreau, J., \& Ramstad, P. (2005). Talentship, talent segmentation and sustainability: A new HR decision science paradigm for a new strategy definition. Human Resource Management, 44(2), 129-136. http://dx.doi.org/10.1002/hrm.20054

Bourdreau, J., \& Ramstad, P. (2007). Beyond HR: The new science of human capital. Boston, MA: Harvard Business School Press.

Brewster, C., Mayrhofer, W., \& Morley, M. (2004). Human resource management in Europe: Evidence of convergence. Elsevier Butterworth-Heinemann, Oxford.

Brislin, R. (1976). Comparative research methodology: Cross-cultural studies. International Journal of Psychology, 11(3), 215-229. http://dx.doi.org/10.1080/00207597608247359 
Buckingham, M., \& Vosburgh, R. (2001). The 21 st century human resources functions: It's the talent stupid. Human Resource Planning, 24(4), 17-23.

Burmeister, W. (2004). Living in Dilbert's world: A cubicle eye's view of job dissatisfaction. Journal of American Academy of Business, 5(1/2), 350-352.

Byham, W. (2001). Are leaders born or made? Workspan, 44(12), 56-60.

Cappelli, P. (2000). A market-driven approach to retaining talent. Harvard Business Review, 78(1), 103-112.

Cappelli, P. (2008). Talent management for the twenty-first century. Harvard Business Review, 86(3), 74-81.

Cheloha, R., \& Swain, J. (2005). Talent management system key to effective succession planning. Canadian HR Reporter, 18(17), 5-8.

Clark, A. (1993). Job satisfaction and gender: Why are women so happy at work? Paper 4, ESRC Research Centre on Micro-Social Change, University of Essex, London.

Clark, A., Oswald, A., \& Warr, P. (1996). Is job satisfaction U-shaped in age? Journal of Occupational and Organizational Psychology, 69(1), 57-81. http://dx.doi.org/10.1111/j.2044-8325.1996.tb00600.x

Coff, R. (1997). Humans assets and management dilemmas: Coping with hazards on the road to Resource-Based Theory. Academy of Management Review, 22(2), 374-402. http://dx.doi.org/10.5465/AMR.1997.9707154063

Collings, D., \& Mellahi, K. (2009). Strategic talent management: A review and research agenda. Human Resource Management Review, 19(4), 304-313. http://dx.doi.org/10.1016/j.hrmr.2009.04.001

Collings, D., \& Scullion, H. (2009). Global staffing: A review and thematic research agenda. International Journal of Human Resource Management, 20(6), 1249-1272. http://dx.doi.org/10.1080/09585190902909806

Collings, D., Scullion, H., \& Vaiman, V. (2011). European perspectives on talent management. European Journal of International Management, 5(5), 453-462. http://dx.doi.org/10.1504/EJIM.2011.042173

Creelman, D. (2004, September). Return on investment in talent management: Measures you can put to work right now. Available from Human Capital Institute, 2121 K Street, N.W., Suite 800, Washington DC 20037 USA.

Crossman, A., \& Abou-Zaki, B. (2003). Job satisfaction and employee performance of Lebanese banking staff. Journal of Managerial Psychology, 18(4), 368-376. http://dx.doi.org/10.1108/02683940310473118

Dickmann, M, Brewster, C., \& Sparrow, P. (2008). International human resource management: A European perspective. Routledge, London.

Elsaid, A., \& Elsaid, E. (2012). Sex stereotyping managerial positions: A cross-cultural comparison between Egypt and the U.S.A. Gender in Management: An International Journal, 27(2), 81-99. http://dx.doi.org/10.1108/17542411211214149

Frank, F., \& Taylor, C. (2004). Talent management trends that will shape the future. Human Resource Planning, 27(1), 33-41.

Gary, A., \& Phillips, V. (1994). Turnover, age and length of service: A comparison of nurses and other staff in the National Health Service. Journal of Advanced Nursing, 19(4), 819-827. http://dx.doi.org/10.1111/j.1365-2648.1994.tb01155.x

Heckman, J. (1979). Sample selection bias as a specification error. Econometrica, 47(1), 153-161. http://dx.doi.org/10.2307/1912352

Heinen, J., \& O'Neill, C. (2004). Managing talent to maximize performance. Employment Relations Today, 31(3), 67-82. http://dx.doi.org/10.1002/ert.20018

Hickson, C., \& Oshagbemi, T. (1999). The effect of age on the satisfaction of academics with teaching and research. International Journal of Social Economics, 26(4), 537-544. http://dx.doi.org/ 10.1108/03068299910215960

Hilton, D. (2000). Hiring and retaining top talent. Credit Union Executive Journal, 40(4), 12-16.

Hofstede, G. (1980). Culture's consequences: International differences in work related values. Beverly Hills, CA: Sage.

Holt Larsen, H., \& Mayrhofer, W. (2006). Managing human resources in Europe. Routledge, London.

Huang, X., \& Van de Vliert, E. (2004). Job level and national culture as joint roots of job satisfaction. Applied Psychology, 53(3), 329-348. http://dx.doi.org/10.1111/j.1464-0597.2004.00174.x 
Hueslid, M., Beatty, R., \& Becker, B. (2005). 'A players' or 'A positions'? The strategic logic of workforce management. Harvard Business Review, 83(12), 110-117.

Hulin, C. (1991). Adaptation, persistence and commitment in organizations. In Dunnette, M. D. and Hough, L. M. (Eds.), Handbook of Industrial and Organizational Psychology. Chicago: Rand McNally.

Jackson, S., \& Schuler, R. (1990). Human resource planning: Challenges for industrial/organizational psychologists. American Psychologist, 45(2), 223-239. http://dx.doi.org/10.1037/0003-066X.45.2.223

Jinnett, K., \& Alexander, J. (1999). The influence of organizational context on quitting intentions: An examination of treatment staff in long-term mental healthcare settings. Research on Aging, 21(2), 176-204. http://dx.doi.org/10.1177/0164027599212003

Kavanaugh, J., Duffy, J., \& Lilly, J. (2006). The relationship between job satisfaction and demographic variables for healthcare professionals. Management Review News, 29(6), 304-325. http://dx.doi.org/10.1108/01409170610683842

Kesler, G. (2002). Why the leadership bench never gets deeper: Ten insights about executive talent development. Human Resource Planning, 25(1), 32-44.

Kirkman, B., \& Shapiro, D. (2001). The impact of cultural values on job satisfaction and organizational commitment in self-managing work teams: the mediating role of employee resistance. Academy of Management Journal, 44(3), 557-569. http://dx.doi.org/10.2307/3069370

Leat, M., \& El-Kot, G. (2007). HRM practices in Egypt: The influence of national context. International Journal of Human Resource Management, 18(1), 147-158. http://dx.doi.org/10.1080/09585190601068557

Lermusiaux, Y. (2005, May). Talent management: A definition. Retrieved May 10, 2017, from http://www.taleo.com/blog/index.php?m=200505

Lewis, R., \& Heckman, R. (2006). Talent management: A critical review. Human Resource Management Review, 16(2), 139-154. http://dx.doi.org/10.1016/j.hrmr.2006.03.001

Locke, E. (1976). The nature and causes of job satisfaction. In M. D. Dunnette (Ed.), Handbook of Industrial and Organizational Psychology. Chicago: Rand McNally.

Luthans, F., Zhu, W., \& Avolio, B. (2006). The impact of efficacy on work attitudes across cultures. Journal of World Business, 41(2), 121-132. http://dx.doi.org/10.1016/j.jwb.2005.09.003

Maguire, S. (1995). Learning to change. European Quality, 2(8), 23-28.

Manlove, E., \& Guzell, J. (1997). Intention to leave, anticipated reasons for leaving and 12-month turnover of child care center staff. Early Childhood Research Quarterly, 12(2), 145-167. http://dx.doi.org/10.1016/S0885-2006(97)90010-7

McDonnell, A. (2011). Still fighting 'the war if talent'? Bridging the science versus practice gap. Journal of Business and Psychology, 26(2), 169-173. http://dx.doi.org/10.1007/s10869-011-9220-y

Mellahi, K., \& Collings, D. (2010). The barriers to effective global talent management: The example of corporate elites in MNEs. Journal of Work Business, 45(2), 143-149. http://dx.doi.org/10.1016/j.jwb.2009.09.018

Mercer, S. (2005). Best-in-class leadership. Leadership Excellence, 22(3), 17.

Michaels, E., Handfield-Jones, H., \& Axelrod, B. (2001). The war for talent. Boston, MA: Harvard Business School Press.

Milliken, F., \& Martins, L. (1996). Searching for common threads: Understanding the multiple effects of diversity in organizational groups. Academy of Management Review, 21(2), 402-433. http://dx.doi.org/10.5465/AMR.1996.9605060217

Nydell, M. (1996). Understanding Arabs: A guide for Westerners. Boston, MA: Intercultural Press.

Olsen, R. (2000). Harnessing the internet with human capital management. Workspan, 43(11), 24-27.

Oshagbemi, T. (1998). The impact of age on the job satisfaction of university teachers. Research in Education, 59, 95-108.

Oshagbemi, T. (2000a). Is the length of service related to the level of job satisfaction? International Journal of Social Economics, 27(3), 213-226. http://dx.doi.org/10.1108/03068290010286546 
Oshagbemi, T. (2000b). Gender differences in the job satisfaction of university teachers. Women in Management Review, 15(7), 331-343. http://dx.doi.org/10.1108/09649420010378133

Parnell, J., \& Hatem, T. (1999). Cultural antecedents of behavioral differences between American and Egyptian managers. Journal of Management Studies, 36(3), 399-418. http://dx.doi.org/10.1111/1467-6486.00142

Pascal, C. (2004). Foreword. In A. Schweyer (Ed.), Talent management systems: Best practices in technology solutions for recruitment, retention and workforce planning. Canada: Wiley.

Rawashdeh, A., Al-Saraireh, A., \& Obeidat, G. (2015). Does organizational culture matter for job satisfaction in Jordanian private aviation companies? International Journal of Information, Business and Management, 7(2), 107-115.

Redford, K. (2005, September). Shedding light on talent tactics. Personnel Today, 20-22.

Romans, J., \& Lardner, L. (2005). Integrated talent management at BD Japan. Strategic HR Review, 4(5), 16-19. http://dx.doi.org/10.1108/14754390580000816

Rothwell, W. (1994). Effective succession planning: Ensuring leadership continuity and building talent from within. New York, NY: Amacom.

Schuler, R., Jackson, S., \& Tarique, I. (2011). Global talent management and global talent challenges: Strategic Opportunities for IHRM. Journal of World Business, 46(4), 506-516. http://dx.doi.org/10.1016/j.jwb.2010.10.011

Scullion, H., \& Collings, D. (2011). Global Talent Management. Routledge, London.

Scullion, H., Collings, D., \& Caligiuri, P. (2010). Global talent management. Journal of World Business, 45(2), 105-108. http://dx.doi.org/10.1016/j.jwb.2009.09.011

Shrader, C., Blackburn, V., \& Iles, P. (1997). Women in Management and Firm Financial Performance: An Exploratory Study. Journal of Managerial Issues, 9(3), 355-372.

Singh, V., Terjesen, S., \& Vinnicombe, S. (2008). Newly appointed directors in the boardroom: How do women and men differ? European Management Journal, 26(1), 48-58. http://dx.doi.org/10.1016/j.emj.2007.10.002

Smart, B. (1999). Topgrading: How leading companies win by hiring, coaching and keeping the best people. Paramus, NJ: Prentice Hall Press.

Smith, P., Kendall, L., \& Hulin, C. (1969). The management of satisfaction in work and retirement: A strategy for the study of attitudes. Skokie, IL: Rand-McNally.

Somers, M. (1996). Modeling employee withdrawal behaviour over time: A study of turnover using survival analysis. Journal of Occupational and Organizational Psychology, 69(4), 315-326. http://dx.doi.org/10.1111/j.2044-8325.1996.tb00618.x

Spector, P. (1997). Job satisfaction: Application, assessment, cause and consequences. Sage Publications, London.

Spector, P. (2008). Industrial and Organizational Psychology: Research and Practice (5th ed.). New York, NY: John Wiley \& Sons.

Tarique, I., \& Schuler, R. (2010). Global talent management: Literature review, integrative framework, and suggestions for future research. Journal of World Business, 45(2), 122-133. http://dx.doi.org/10.1016/j.jwb.2009.09.019

Teagarden, M., Meyer, J., \& Jones, D. (2008). Knowledge sharing among high-tech MNCs in China and India: Invisible barriers, best practices and next steps. Organizational Dynamics, 37(2), 190-202. http://dx.doi.org/10.1016/j.orgdyn.2008.02.008

Todd, C., \& Deery-Schmitt, D. (1996). Factors affecting turnover among family child care providers: A longitudinal study. Early Childhood Research Quarterly, 11(3), 351-376. http://dx.doi.org/10.1016/S0885-2006(96)90012-5

Tucker, E., Kao, T., \& Verma, N. (2005). Next generation talent management: Insights on how workforce trends are changing the face of talent management. Business Credit, 106(7), 20-27.

Tymon, W., Strumpf, S., \& Doh, J. (2010). Exploring talent management in India: The neglected role of intrinsic rewards. Journal of World Business, 45(2), 109-121. http://dx.doi.org/10.1016/j.jwb.2009.09.016

Vaiman, V., \& Holden, N. (2011). Talent management's perplexing landscape in Central and Eastern Europe, in Scullion, H. and Collings, D. (Eds), Global Talent Management (pp. 178-193). Routledge, London. 
Vecernik, J. (2003). Skating on thin ice: A comparison of work values and job satisfaction in CEE and EU countries. International Journal of Comparative Sociology, $44(5), \quad 444-471$. http://dx.doi.org/10.1177/002071520304400502

Vicker, N. (2003). Examination of employee demographics and voluntary reasons for leaving stated during the exit interview process. The University of Nebraska: Lincoln.

Walker, J., \& Larocco, J. (2002). Talent pools: The best and the rest. Human Resource Planning, 25(3), 12-14.

Werner, O., \& Campbell, D. (1976). Translating, working through interpreters, and the problem of decentering, in Naroll, R. and Cohen, R. (Ed.), A handbook of method in cultural anthropology, American Museum of Natural History (pp. 398-420). New York, NY.

Yeung, A., Warner, M., \& Rowley, C. (2008). Growth and globalization: Evolution human resource practices in Asia. Human Resource Management, 47(1), 1-13. http://dx.doi.org/10.1002/hrm.20194

Yousef, D. (2001). Islamic work ethic: A moderator between organizational commitment and job satisfaction in cross-cultural context. Personnel Review, 30(2), 152-169. http://dx.doi.org/10.1108/00483480110380325

Zhang, J. (1991). Modernization, interpersonal power, and conformity: a cross-cultural study of significant others' influences on adolescents. Brigham Young University, Provo, UT. 